\title{
EXOTIC ARBUSCULAR MYCORRHIZAL FUNGI AND NATIVE DARK SEPTATE ENDOPHYTES ON THE INITIAL GROWTH OF Paspalum millegrana GRASS ${ }^{1}$
}

\section{LARISSA DE SOUZA GOIS ${ }^{2}$, JOHNY DE JESUS MENDONÇA ${ }^{2}$, JUAN LOPES TEIXEIRA ${ }^{2}$, CAROLINA MANGIERI DE OLIVEIRA PRADO ${ }^{3}$, FRANCISCO SANDRO RODRIGUES HOLANDA ${ }^{2}$,REGINA HELENA MARINO ${ }^{2 *}$}

\begin{abstract}
Arbuscular mycorrhizal fungi (AMF) and dark septate endophytic fungi (DSE) promote increase in plant biomass, depending on the soil and climate conditions and the interactions with the host plant. The objective of this study was to evaluate the interaction of exotic arbuscular mycorrhizal fungi and native DSE fungi on the initial growth of $P$. millegrana. A completely randomized experimental design comprising the Paspallum millegrana cutilvar with the following treatments: control - without AMF, and three exotic AMF isolates (UFLA351 - Rhizoglomus clarum, UFLA372 - Claroideoglomus etunicatum and UFLA401 Acaulospora morrowiae), with four replications each. P. millegrana grass was colonized by exotic AMF by $R$. clarum (UFLA351, 11.9\%), C. etunicatum (UFLA372, 39.6\%), and A. morrowiae (UFLA401, 51.2\%). $P$. millegrana was also colonized by native DSE fungi, but these did not interfere with the colonization by exotic AMF and plant development. P. millegrana is responsive to the inoculation of UFLAs isolates of exotic AMF, which may contribute to the grass growth and survival under field conditions. The process of surface disinfestation of seeds does not eliminate endophytic microorganisms, whose presence may influence plant colonization by AMF, as well as development of the host plant.
\end{abstract}

Keywords: Poaceae. Filamentous fungi. Symbiosis. Plant growth. Mycotrophy.

\section{FUNGOS MICORRÍZICOS ARBUSCULARES EXÓTICOS E ENDOFÍTICOS "DARK SEPTATE" NATIVOS NO CRESCIMENTO INICIAL DE Paspalum millegrana}

\begin{abstract}
RESUMO - Os fungos micorrízicos arbusculares (FMA) e os endofíticos "dark septate" (DSE) podem promover o incremento da biomassa vegetal, a depender das condições edafoclimáticas e da interação com a planta hospedeira. O objetivo deste trabalho foi avaliar a interação de fungos micorrízicos arbusculares exóticos e fungos endofíticos DSE nativos no crescimento inicial de Paspalum millegrana Schrad. ex Schult. O delineamento experimental utilizado foi inteiramente casualizado composto pelo cultivo de Paspallum millegrana em quatro tratamentos (controle - sem FMA, e três isolados de FMA exóticos: UFLA351 Rhizoglomus clarum; UFLA372 - Claroideoglomus etunicatum e UFLA401 - Acaulospora morrowiae), com quatro repetições. O capim P. millegrana é colonizado por FMA exóticos das espécies R. clarum (UFLA351; 11,9\%), C. etunicatum (UFLA372; 39,6\%) e A. morrowiae (UFLA401; 51,2\%). O P. millegrana foi colonizado por fungos endofíticos DSE nativos, mas estes não interferem na colonização por FMA exóticos e no desenvolvimento das plantas. O P. millegrana foi responsivo à inoculação dos isolados UFLAs de FMA exóticos, o que pode contribuir para o crescimento e sobrevivência do capim em condições de campo. E o processo de desinfestação superficial das sementes não elimina micro-organismos endofíticos, cuja presença pode influenciar na colonização das plantas por FMA, bem como no desenvolvimento da planta hospedeira.
\end{abstract}

Palavras-chave: Poaceae. Fungos filamentosos. Simbiose. Crescimento vegetal. Micotrofia.

\footnotetext{
${ }^{*}$ Corresponding author

${ }^{1}$ Received for publication in $12 / 12 / 2018$; accepted in $02 / 05 / 2019$.

Paper extracted from the scientific initiation work of the first author.

${ }^{2}$ Departament of Agronomic Engineering, Universidade Federal de Sergipe, São Cristóvão, SE, Brazil; lary18gois@gmail.com - ORCID: 0000-0003-2134-0509, mendonça.johny@yahoo.com.br - ORCID: 0000-0002-7690-6234, juan_lt_1@hotmail.com - ORCID: 0000-00026053-8692, fholanda@infonet.com.br - ORCID: 0000-0001-6812-6679, rehmarino@hotmail.com - ORCID: 0000-0002-7295-3746.

${ }^{3}$ Laboratory of Organic Chemistry, Instituto Tecnológico de Pesquisa do Estado de Sergipe, Aracaju, SE, Brazil; carolina.mangieri@itps.se.gov.br - ORCID: 0000-0002-7973-268X.
} 


\section{INTRODUCTION}

Soil contains divers microorganisms that play many roles in maintaining the ecological balance. Among the soil microorganisms, arbuscular mycorrhizal fungi (AMF) and dark septate endophytic (DSE) fungi influence plant growth, plant biomass, and/or the survival of cultivated species under adverse conditions (AZEVEDO, 1998; YAN et al., 2015).

AMF are biotrophic organisms capable of association with more than $80 \%$ of plant species. Through this association, they are able to increase water and nutrient uptake, and supply directly to the cells in the root cortex. In return, the host plants provide the symbiotic fungus with photoassimilates for nutrition. By these interactions, the AMF promotes plant growth (SANTOS et al., 2018a); induces the defense system against pathogens and/or pests (VOLPE et al., 2018; HEIDJEN et al., 2015); increases the absorption of water and nutrients and reduce the consumption of mineral fertilizers (ZIANE et al., 2017); reducing nitrogen and phosphorus losses in the soil (TEUTSCHEROVA et al., 2019; OKONJI et al., 2018), and promoting tolerance to drought and salinity (RIVERO et al., 2018). However, the beneficial effects of AMF symbiosis on the host plant are not restricted to plant growth. Silva et al. (2016) observed that AMF secretes the 'glomalin' glycoprotein that is capable of soil particles aggregation, and minimizes soil erosion, which is important to the recovery of degraded areas.

Colonization of plants by AMF is characterized by the presence of structures such as hyphae, appressorium, arbuscules, vesicles and sporocarps, depending on the mycorrhizal species. The hyphae are structures responsible for the absorption of water and nutrients. They also differentiate and form vesicles, arbuscules, appressorium and sporocarps. The plants colonization process begins with the sporocarps germination, which leads to the appressoriumforming hyphae required for adhering to the host plant, although its absence does not allow infection. The arbuscules and vesicles are formed after the AMF enters the plant. The arbuscules are ephemeral structures, that promote the transfer of nutrients between the symbionts. The vesicles are structures responsible for storing energy for the symbiotic fungi. The sporocarps are reproductive structures that are important for the spread and survival of the AMF (HEIJDEN et al., 2015; JALONEN et al., 2013). However, plant mycorrhizal colonization does not always guarantee an increase in plant biomass, once it depends on the interaction between the host plant and the AMF (SANTOS et al., 2018a,b).

The dark septate endophytic (DSE) fungi, characterized by melanized and septate hyphae, also a promoter of plant growth, probably due to its role in increasing nutrient availability (RIBEIRO et al., 2011). Few studies have investigated the interactions of DSE, AMF and grasses. The AMF-related studies should consider that heat treatment of substrates, and/or surface seed disinfection does not guarantee total elimination of endophytic microorganisms (BARROW; OSUMA, 2002; PEREIRA et al., 2011). Yan et al. (2015) reported that endophytic microorganisms may stimulate or inhibit other soil organisms. Thus, the presence of these microorganisms can interfere with symbiosis, depending on the AMF-DSE interactions as well as influencing the AMF colonization (SANTOS et al., 2018a,b).

In the Lower São Francisco region, Paspalum millegrana grass, a native species in the Americas, has been used to stabilize slopes because of its high plant biomass and fine roots, improving soil shear strength and soil particles aggregation (HOLANDA et al., 2017; MACHADO et al., 2015; HOLANDA; ROCHA; OLIVEIRA, 2008; OLIVEIRA et al., 2013).

The high biomass formation of Paspalum millegrana grass may be associated with native microbiota composed of AMF and DSE, whose interaction has been reported only between native AMF and $P$. dilatatum, $P$. natatu, $P$. scrobiculatum, and $P$. notatum grass (CAVAGNARO et al., 2014; CUI et al., 2015; CHANNABASAVA; LAKSHMAN; MUTHUKUMAR, 2015; MONROY et al., 2013). However, in the association of AMF with Paspalum grass it must be considered that the use of native AMF inoculants may or may not stimulate growth, depending on the relationship between the endophytic microorganisms and the host plant (SANTOS et al., 2018a,b).

In the present study, the hypothesis to be tested was that endophytic microorganisms such as exotic AMF and native DSE colonize Paspalum millegrana grass and that the presence of these microorganisms influences growth and development of this grass. Thus, if $P$. millegrana is colonized by AMF and DSE, it may result in increased plant growth, increasing the survival of these plants under field conditions, and promoting soil conservation by reducing erosion, as observed by Machado et al. al. (2015) with the vetiver grass (Chrysopogon zizanioides (L.) Roberty). The objective of this work was to evaluate the effects of the interaction of exotic AMF and native DSE endophytic fungi on the initial growth of Paspalum millegrana grass in a greenhouse.

\section{MATERIAL AND METHODS}

\section{Experimental design}

The experimental design was completely randomized with four treatments (control - without 
fungi and three isolates of AMF: UFLA351 Rhizoglomus clarum; UFLA372 - Claroideoglomus etunicatum and UFLA401 - Acaulospora morrowiae), with four repetitions.

The bioassay was performed in greenhouse, in the municipality of São Cristóvão, Sergipe, Northeastern Brazil. According to Köppen-Geiger, the climate classification in the municipality is As, tropical and rainy in winter and dry in the summer, whose average temperature is $25.3^{\circ} \mathrm{C}$ and annual average rainfall is $1372 \mathrm{~mm}$ (SEMARH, 2018; WHITE; SILVA, 2016).

\section{Production of mycorrhizal inoculant}

The UFLA mycorrhizal isolates were provided by the Laboratory of Soil Microbiology of the Universidade Federal de Lavras (UFLA). The isolates were cultivated in a sandy soil-based substrate and mixed with mycorrhizal propagules (2: 1 ratio of sand: inoculant), in pots.

The sandy soil used was collected in a fallow area of "Espaço de Vivência Agroecológica" (EVA) belonging to Universidade Federal de Sergipe, $15 \mathrm{~cm}$ deeper. The sandy soil was classified as sandy-loam with $\mathrm{pH} 6.9,4.7 \mathrm{~g} \mathrm{Kg}^{-1}$ organic matter, $1.3 \mathrm{cmolc} \mathrm{dm}$ ${ }^{-3} \mathrm{CTC}, 76.5 \% \mathrm{~V}, 8.0 \mathrm{mg} \mathrm{Kg}^{-1}$ potassium and $8.0 \mathrm{mg}$ $\mathrm{Kg}^{-1}$ phosphorus.

The soil was autoclaved at $120{ }^{\circ} \mathrm{C}$ and 1 atm for $1 \mathrm{~h}$ and repeated after $24 \mathrm{~h}$. Upon cooling, the inoculant was distributed between two layers of sandy soil, where sorghum seeds were sow. The irrigation system was repeated four times daily and activated for 1-2 min. Irrigation interval was $6 \mathrm{~h}$. The plants were cultivated in the greenhouse, with micro sprinkler irrigation for 60 days. Thereafter, the shoot of the sorghum plants was cut and irrigation was suspended for 25 days to stimulate the formation of mycorrhizal propagules. Root fragments of sorghum colonized by mycorrhizal isolates and the sandy soil containing hyphae and spores were used as inoculants. The number of mycorrhizal spores present in the inoculant was determined according to the methodology of Gerdemann and Nisolson (1963).

\section{Identification of endophytic microorganisms in the seeds of $P$. millegrana}

For identification of endophytic microorganisms, $P$. millegrana seeds were surface disinfected with $70 \%$ alcohol for $1 \mathrm{~min}$., $0.1 \%$ sodium hypochlorite for $1 \mathrm{~min}$. and followed by three washes using autoclaved distilled water for 1 min. each (ALFENAS; MAFIA, 2007). The disinfected seeds were individually transferred to a gerbox box containing filter paper moistened with autoclaved distilled water. The seeds were placed in an incubator maintained at $25 \pm 1{ }^{\circ} \mathrm{C}$, without photoperiod, for 10 days. The observed endophytic fungi were identified based on the reproductive structures under the optical microscope.

\section{Production of $P$. millegrana seedlings}

P. millegrana grass seedlings were obtained after sowing the disinfected seeds as described in the previous item, in pots containing autoclaved sandy soil and moistened with autoclaved distilled water. The seed germination rate of $P$. millegrana was $21 \%$, after 10 days of sowing.

\section{Bioassay for evaluation of microbial interaction in $P$. millegrana grass growth}

P. millegrana seedlings of $2 \mathrm{~cm}$ height were selected and transferred to $18.5 \mathrm{~cm}$ high and, $5.5 \mathrm{~cm}$ diameter $\left(146.4 \mathrm{~cm}^{3}\right)$ tubes containing autoclaved sandy soil and coconut powder (non-autoclaved, 2: 1 substrate and the mycorrhizal inoculant). In the treatments, mycorrhizal isolates were distributed with the inoculants containing, on an average, 20 spores per $50 \mathrm{~g}$ sandy soil and fragments of roots of the sorghum plant. In the control treatment, only the autoclaved sandy soil and coconut powder $(2: 1)$ were used, without mycorrhizal inoculant.

During cultivation, the addition of fertilization was performed twice after $15^{\text {th }}$ days of transplanting, with interval of one week between fertilizations with $3 \mathrm{~mL}$ of a solution prepared with 3 $\mathrm{g} \mathrm{L}^{-1}$ of the commercial fertilizer consisting $15 \%$ nitrogen $(\mathrm{N})$ and $14 \%$ potassium $\left(\mathrm{K}_{2} \mathrm{O}\right)$ were applied. After 15 days of the two fertilizations, $3 \mathrm{~mL}$ of a solution prepared with $10 \mathrm{~g} \mathrm{~L}^{-1}$ of the commercial fertilizer composed of $13 \%$ nitrogen $(\mathrm{N}), 5 \%$ phosphorus $\left(\mathrm{P}_{2} \mathrm{O}_{5}\right), 13 \%$ potassium $\left(\mathrm{K}_{2} \mathrm{O}\right), 5 \%$ sulfur (S), $1 \%$ calcium $(\mathrm{Ca}), 0.08 \%$ magnesium $(\mathrm{Mg}), 0.2 \%$ iron $(\mathrm{Fe}), \quad 0.15 \%$ zinc, $0.08 \%$ manganese $(\mathrm{Mn})$, $0.04 \%$ of boron (B), $0.05 \%$ of copper $(\mathrm{Cu})$ and $0.005 \%$ of molybdenum (Mo) and repeated biweekly.

\section{Attributes evaluated}

The analyzed variables were: plant height, root length, dry shot mass, dry root mass, mycorrhizal dependence, colonization mycorrhizal, mycorrhizal structures, colonization by DSE fungi and foliar phosphorus content after 90 days of cultivation.

Plant height and root length were determined using a standard millimeter ruler and measurements was recorded from the tip of the plant. The dry shoot mass (DSM) and dry root mass (DRM) were determined weighing the samples in semi-analytical balance. Drying the plant material (shoot and root) was performed in a forced circulation air at a mean temperature of $60{ }^{\circ} \mathrm{C}$ until constant mass was achieved.

Total dry mass was calculated as the sum of 
the dry shoot and dry root mass. The mycorrhizal dependence (MD) was evaluated on root length, dry root mass and total dry mass, and in relation the control (without AMF), according to Plenchette, Fortin and Furlani (1983) methodology and determined by equation 1 : $M D(\%)=[(A-B) / A] \times 100$ where A mycorrhizal plant value and $\mathrm{B}$ - control plant value (without AMF). The classification of mycorrhizal dependence was described by Machineski, Balota and Souza (2011), in which plants with values $>75 \%$ were classified with excessive dependence; from 50 to $75 \%$ with high dependence; 25 to $50 \%$ with moderate dependence and $<25 \%$ with marginal dependence or does not respond to inoculation.

Mycorrhizal colonization (MC) and the percentage of appressorium, hyphae, vesicles and arbuscules were evaluated by the intersection method, and according to Giovannetti and Mosse (1980) with modifications. Root fragments were stained with Tripan blue were analyzed with the aid of an optical microscope and slide grids $(5 \mathrm{~mm} \times 5$ $\mathrm{mm})$ at $400 \mathrm{x}$ magnification. The slides were examined for colonization and the presence of mycorrhizal structures (hyphae, appressorium, arbuscules, vesicles and spores). The percentage of $\mathrm{MC}$ was determined by MC (\%) = (C/D) x 100), where, $\mathrm{C}$ is the total number of colonized fragments, and $\mathrm{D}$ refers to the total number of colonized and uncolonized fragments. The percentage of mycorrhizal fungi (Hyphae - $\mathrm{H}$, appressorium Appr, vesicles - Ve, arbuscules - Arb and sporocarps - Spo) observed during the evaluation of the mycorrhizal colonization of selected root fragments was determined by MC $(\%)=((\mathrm{MFSN}) /(\mathrm{TNCF}) \mathrm{x}$ $100)$, where, MFSN is the mycorrhizal fungal structure number, and TNFC, refers to the total number of colonized fragments. The types of arbuscules (Arum or Paris) were identified following
Dickson, Smith and Smith (2007).

The DSE fungi present in the root fragments were identified based on the presence of melanized and septate hyphae (RIBEIRO et al., 2011). The percentage of DSE endophytic was determined by equation 3: $\operatorname{DSE}(\%)=((\mathrm{E} / \mathrm{F}) \times 100)$, where, $\mathrm{E}$ is number of fragments colonized by dark septate endophytic fungi, and $\mathrm{F}$ is total number of root analyzed fragments.

The leaf phosphorus content in the leaf dry mass was determined according to Malavolta, Vitti and Oliveira (1997).

\section{Statistical analysis}

Data were subjected to normality analysis using the Kolmogorov-Smirnov, Cramér-Von Mises, Anderson-Darling, Kuiper, Watson, Lilliefors and/or Shapiro-Wilk tests at 5\% probability. After that, the data was subjected to Analysis of Variance (ANOVA) and Tukey's test was applied at 5\% significance to comparison the means. Data of mycorrhizal colonization, DSE colonization, dry shoot mass, dry root mass, total dry mass, root length, and leaf phosphorus content were also subjected to correlation analysis and test at 1 and $5 \%$ significance. All statistical analyses were performed using the SISVAR program.

\section{RESULTS AND DISCUSSION}

The cultivated plants of $P$. millegrana with UFLA351 showed $11.9 \%$ of mycorrhizal colonization without any significant differences to the $39.6 \%$ and $51.2 \%$ of inoculation to the mycorrhizal isolates UFLA372 and UFLA401, respectively (Table 1).

Table 1. Mycorrhizal colonization (MC), percentage of hyphae (H), appressorium (Appr), arbuscules (Arb), vesicles (Ves), sporocarps associated with root fragments (Spo) and colonization by native DSE endophytic fungi in plants of Paspalum millegrana cultivated for 90 days with exotic AMF isolates.

\begin{tabular}{lccccccc}
\hline Trat. ${ }^{{ }^{\prime}}$ & $\begin{array}{c}\text { MC } \\
(\%)\end{array}$ & $\begin{array}{c}\mathrm{H} \\
(\%)\end{array}$ & $\begin{array}{c}\text { Appr } \\
(\%)\end{array}$ & $\begin{array}{c}\text { Arb } \\
(\%)\end{array}$ & $\begin{array}{c}\text { Ves } \\
(\%)\end{array}$ & $\begin{array}{c}\text { Spo } \\
(\%)\end{array}$ & $\begin{array}{c}\text { DSE } \\
(\%)\end{array}$ \\
\hline Control & $5.9 \pm 3.8 \mathrm{a}^{2}$ & $0.0 \pm 0.0 \mathrm{~b}$ & $0.0 \pm 0.0 \mathrm{a}$ & $0.0 \pm 0.0 \mathrm{~b}$ & $0.0 \pm 0.0 \mathrm{~b}$ & $50.0 \pm 17.7 \mathrm{a}$ & $16.9 \pm 9.2 \mathrm{a}$ \\
UFLA351 & $11.9 \pm 5.8 \mathrm{a}$ & $32.5 \pm 29.5 \mathrm{~b}$ & $37.5 \pm 17.8 \mathrm{a}$ & $27.5 \pm 12.0 \mathrm{ab}$ & $0.0 \pm 0.0 \mathrm{~b}$ & $0.0 \pm 0.0 \mathrm{a}$ & $8.3 \pm 6.7 \mathrm{a}$ \\
UFLA372 & $39.6 \pm 17.6 \mathrm{a}$ & $119.2 \pm 54.2 \mathrm{a}$ & $8.1 \pm 9.5 \mathrm{a}$ & $10.7 \pm 7.4 \mathrm{~b}$ & $8.1 \pm 9.5 \mathrm{ab}$ & $5.8 \pm 7.1 \mathrm{a}$ & $17.1 \pm 14.6 \mathrm{a}$ \\
UFLA401 & $51.2 \pm 20.0 \mathrm{a}$ & $71.6 \pm 19.3 \mathrm{ab}$ & $34.9 \pm 13.7 \mathrm{a}$ & $64.1 \pm 31.0 \mathrm{a}$ & $31.5 \pm 12.1 \mathrm{a}$ & $25.4 \pm 24.7 \mathrm{a}$ & $8.7 \pm 4.2 \mathrm{a}$ \\
\hline
\end{tabular}

${ }^{1}$ Treatments: control - without AMF; UFLA351 - R. clarum; UFLA372 - C. etunicatum; and UFLA401 - A. morrowiae; ${ }^{2}$ Means followed by the same letter, in the column, do not differ by the Tukey's test at $5 \%$ probability; ${ }^{3} \mathrm{~ns}=$ nonsignificant, *significant at $5 \%$ probability $(0.01 \leq \mathrm{p}<0.05)$ and $* *$ significant at $1 \%$ probability $(\mathrm{p}<0.01)$ by the t-test.

Cavagnaro et al. (2014) showed mycorrhizal colonization of 63 to $80 \%$ in $P$. dilatatum with values higher than those observed in this study, probably resulting from the some specific interactions between the exotic mycorrhizal fungal ULFA isolates and P. millegrana.
Mycorrhizal colonization of $P$. millegrana grass was characterized by the presence of appressorium, hyphae, vesicles, arbuscules and spores, depending on the treatment (Table 1), indicating an interaction between AMF and $P$. millegrana grass (HEIJDEN et al. al., 2015), 
regardless of other factors.

In the treatment containing UFLA372, the presence of hyphae was 3.7 times more hyphae compared to UFLA351, but without significant differences compared to UFLA401 (Table 1). This effect may be correlated to the greater dissemination potential of UFLA372 and may should be generalist in relation to the interaction with plant species, as observed in the studies on vetiver grass (SANTOS et al., 2018a) and Fabaceae Gliricidia sepium (Jacq.) Steud. (SANTOS et al., 2018b).

Balestrini et al. (2014) and Heijden et al. (2015) cited that arbuscules are important structures to provide nutrients to the host plants. Dickson, Smith and Smith (2007) observed the formation of arbuscules in poaceous members Arum and Paris, which are common in grasses, such as in $P$. millegrana inoculated with UFLA isolates. However, in treatments UFLA372 and UFLA401, mycorrhizal colonization was of the vesicular-arbuscular type and in UFLA351, was arbuscular type. In P. millegrana cultivated with UFLA401, a significantly higher percentage of arbuscules $(64.1 \%)$ was observed compared to UFLA372 (10.7\%), although no such difference was observed under UFLA351 treatment. Regarding to the vesicles, there was no difference between the treatments UFLA372 and UFLA401 (Table 1).

Jalonen et al. (2013) mentioned that the relationship between arbuscules and vesicles is an indicator of the cost-benefit relationship of the AMFplant symbiosis. In the control treatment, the arbuscules: vesicles ratio was null due to the absence of these two mycorrhizal structures, which characterizes the lack of symbiosis and, no nutrient sharing among the symbionts. In P. millegrana grass cultivated with UFLA351, the arbuscules: vesicles ratio has been also null, as also observed in vetiver grass cultivated with the same mycorrhizal isolate (SANTOS et al., 2018a). This result is due only to the absence of vesicles, which may be beneficial to the plant. The lack of such structures are energysaving and represent low consumption of carbon source for AMF maintenance, mainly in low fertility soils (TRESEDER; ALLEN, 2002).

The absence of vesicles may also be a result of the interaction of the microbiota with the host plant. Santos et al. (2018b) reported the presence of vesicles in Gliricidia sepium cultivated with UFLA351, but there was no correlation to nodules formed by nitrogen fixing bacteria. However, these authors observed that in the treatment with UFLA401, vesicle formation was inhibited as nodulation by nitrogen-fixing bacteria increased. Vesicle formation depends on the AMF $\mathrm{x}$ plant interaction, and the nutrition supply of the associated plant to other microorganisms (OKONJI et al., 2018).

In the treatments with UFLA372 and UFLA401, the arbuscules: vesicles ratio was 0.75 and 0.99 , respectively. This results in a noncompetitive interaction between these isolate and the $P$. millegrana grass. A high arbuscules/vesicles ratio indicates a benefit to symbiosis and plant growth (JALONEN et al., 2013). However, the formation of arbuscules and vesicles may vary depending of the time of the year (LOPES et al., 2018).

Garcia and mendoza (2008) reported that the colonization of $P$. vaginatum was predominantly of arbuscular type in the spring, but was vesicular in the summer. When $P$. millegrana was cultivated with exotic AMF starting in the spring (early October) and harvested in the summer (December), was observed higher percentage of arbuscules compared to the vesicles. In contrast, Santos et al. (2018a) observed that the colonization in vetiver grass was of the vesicular type between the spring and summer seasons. Thus, the presence of vesicles may be influenced by the environment, and also by hostplant interaction. In general, the greater the number of arbuscules in the spring/summer in P. millegrana grass, the better the nutrients availability, such as nitrogen and phosphorus, promoting the plants growth and development, mainly in low fertility soils in the cultivated regions of this species in Sergipe state (HOLANDA et al., 2017).

Regarding the percentage of mycorrhizal sporocarps associated with root fragments in $P$. millegrana, no significant difference between treatments with UFLA isolates and control was observed. In the control (without AMF), the mycorrhizal sporocarps were up to $5.9 \%$ in the mycorrhizal colonization of $P$. millegrana. However, none of important structures in the fungus-plant symbiosis, such as arbuscules, vesicles and extrarradicular hyphae was found. This may be due to the lack of appressorium, which are necessary during the initial colonization of the host plant (HEIDJEN et al., 2015). In addition, the treatment of the sandy soil substrate at high temperature and pressure during autoclaving may have compromised the viability of the native AMF, which had no intraradicular colonization either by vesicles, arbuscules or hyphae. Barrow and Osuna (2002) reported that the use of high temperatures and/or sterilization processes of substrates does not eliminate the endophytic fungi. This may explain the presence of these microorganisms in all the treatments, but no significant differences amongst them, even after substrate sterilization for $P$. millegrana cultivation (Table 1).

Pereira et al. (2011) and Santos et al. (2018b) also observed that surface-disinfected seeds contain DSE fungi. Fungi such as Alternaria sp., Curvularia sp., Nigrospora sp., and Helmintosporium sp. were identified in the disinfected seeds used in the seedling production. This may have contributed to the roots colonization of $P$. millegrana as DSE fungi in all treatments, as reported by Ribeiro et al. (2011). However, in the colonization of $P$. millegrana root 
fragments were difficult to identify the DSE fungi. Only melanized septate hyphae was observed, similar to Uma et al. (2012). Thus, the endophytic fungi found in all the treatments may have originated from the seeds from the seedling production process (PEREIRA et al., 2011; SANTOS et al., 2018b). The presence of these microorganisms might be related to absence of elimination even after autoclaving of the culture substrate, as mentioned by Barrow and Osuna (2002).

The presence of these native DSE fungi may influence growth of $P$. millegrana grass, because these microorganisms may be antagonistic to other organisms and influence symbiosis with AMF (YAN et al., 2015); SANTOS et al., 2018a,b). Dupont et al. (2015) emphasized that endophytic microorganisms are capable of influencing plant metabolism and development, which may also mask the effect of mycorrhizal isolates on host plant growth.

In $P$. millegrana, colonization by DSE endophytic fungi DSE is not correlated to mycorrhizal colonization in the control $(\mathrm{r}=0.02 ; \mathrm{p}>$ $0.05)$, UFLA $351(\mathrm{r}=0.90, \mathrm{p}>0.05)$, UFLA $372(\mathrm{r}$ $=0.35, \mathrm{p}>0.05)$ e UFLA $411(\mathrm{r}=0.34, \mathrm{p}>0.05)$.
Thus the hypothesis that DSE influences AMF colonization, could not be confirmed, in opposition to the findings reported by Uma et al. (2012) in tree species and vetiver grass (SANTOS et al., 2018a). Mandyam and Jumpponen (2008) reported variations in interactions between mycorrhizal and endophytic fungi depending of the host plant growing season and environmental conditions. These factors may influence the interactions of AMF and DSE fungi in P. millegrana. However, the hypothesis that DSE fungi influences mycorrhizal colonization, also depends on the microbial interaction with the host plant. Under UFLA372 treatment there was no influence of the DSE contrary to Santos et al. (2018a) report, studying vetiver grass.

In relation to growth of $P$. millegrana observed that plant height, dry root mass, and root length did not differ significantly between the control and treatments with UFLAs isolates. Dry shoot mass and total dry mass of plants cultivated with UFLA372 were found to be significantly higher than those obtained for the control plants, but no such differences were observed with UFLA351 (Table 2).

Table 2. Plant height (PH), dry shoot mass (DSM), dry root mass (DRM), total dry mass (TDM), root length (RL) and leaf phosphorus content (leaf $\mathrm{P}$ ) of $P$. millegrana cultivated with exotic AMF after 90 days of transplanting.

\begin{tabular}{ccccccc}
\hline Trat. $^{1}$ & PH $(\mathrm{cm})$ & DSM $(\mathrm{g})$ & DRM $(\mathrm{g})$ & TDM $(\mathrm{g})$ & RL $(\mathrm{cm})$ & ${\text { Leaf P }\left(\mathrm{g} \mathrm{Kg}^{-1}\right)}^{2}$ \\
\hline Control & $43.9 \pm 16.2 \mathrm{a}^{2}$ & $0.4 \pm 0.3 \mathrm{~b}$ & $0.2 \pm 0.2 \mathrm{a}$ & $0.5 \pm 0.4 \mathrm{~b}$ & $14.5 \pm 8.2 \mathrm{a}$ & $3.8 \pm 0.7 \mathrm{~A}$ \\
UFLA351 & $60.3 \pm 6.9 \mathrm{a}$ & $0.4 \pm 0.2 \mathrm{ab}$ & $0.3 \pm 0.1 \mathrm{a}$ & $0.7 \pm 0.2 \mathrm{ab}$ & $19.5 \pm 1.8 \mathrm{a}$ & $2.1 \pm 0.4 \mathrm{~B}$ \\
UFLA372 & $51.3 \pm 21.5 \mathrm{a}$ & $0.8 \pm 0.3 \mathrm{a}$ & $0.5 \pm 0.2 \mathrm{a}$ & $1.3 \pm 0.4 \mathrm{a}$ & $19.7 \pm 1.9 \mathrm{a}$ & $2.2 \pm 0.7 \mathrm{~B}$ \\
UFLA401 & $64.1 \pm 6.8 \mathrm{a}$ & $0.7 \pm 0.1 \mathrm{ab}$ & $0.4 \pm 0.1 \mathrm{a}$ & $1.1 \pm 0.2 \mathrm{ab}$ & $20.5 \pm 1.1 \mathrm{a}$ & $1.9 \pm 0.4 \mathrm{~B}$ \\
\hline
\end{tabular}

${ }^{1}$ Treatments: control - without AMF; UFLA351 - R. clarum; UFLA372 - C. etunicatum; and UFLA401 - A. morrowiae; ${ }^{2}$ Means followed by the same letter, in the column, do not differ by the Tukey's test at $5 \%$ probability.

On the leaf phosphorus content, $P$. millegrana plants grown in control had a significant increase from 42.1 to $50.0 \%$ in relation to the treatments with UFLAs isolates (Table 2). This may be due to the higher phosphorus consume during the interaction of $P$. millegrana and mycorrhizal isolates. This symbiosis is recognized occurring with energy expenditure (HEIJDEN et al., 2015). In the control, no characteristic structures were observed in the symbiosis, as previously discussed. In addition, phosphorus consumption was minimal due to absence of active fungus-plant symbiosis.

Barrow and Osuna (2002) observed that the interaction between mycorrhizal and endophytic fungi may increase the phosphorus content in plants. In $P$. millegrana, the phosphorus content was positively correlated with mycorrhizal colonization only in the treatment with UFLA372 $(\mathrm{r}=0,9871 ; \mathrm{p}<$ $0,01)$.
The lowest leaf phosphorus content in the $P$. millegrana plants grown with the UFLAs isolates, in relation to the control, differs from the results mentioned by Garcia and Mendonza (2008). According to these authors, the mycorrhizal colonization of $P$. vaginatum resulted in an increase of nitrogen and phosphorus in the plant. Channabasava, Lakshman and Muthukumar (2015) also observed increased levels of phosphorus, potassium, calcium, magnesium and sodium in the biomass of $P$. scrobiculatum inoculated with Rhizophagus fasciculatus of the AMF. However, Gerlach et al. (2015) emphasized that mycorrhizal plants may have altered metabolism and nutrient levels in the plant, which explain our results.

Newsham (2011) reported that plants colonized by DSE fungi result in root dry mass increase from 52 to $138 \%$. However, in the control treatment, there was no correlation between 
colonization by DSE fungi and dry mass variables. Root length, however, was negatively correlated to leaf phosphorus content $(\mathrm{r}=-0,9588 ; 0,01 \leq \mathrm{p}$ $<0,05)$. Phosphorus was accumulated in the leaves instead of favoring root growth.

Dry shoot mass, dry root mass, root length and total dry mass of plants grown with UFLA isolates were not correlated to colonization by native AMF and native DSE fungi. However, $P$. millegrana plants were responsive to the inoculation of the isolates UFLA351, UFLA372 and UFLA401, resulting in an increase from 25.1 to $29.1 \%$ in root length, from 32.9 to $54.0 \%$ in dry root mass and from 32.9 to $53.4 \%$ in the total dry mass compared to the control, when evaluated based on mycorrhizal dependence. There was no significant difference in the mycorrhizal dependence on root length, dry root mass and total dry mass between treatments with UFLA isolates (Figure 1).

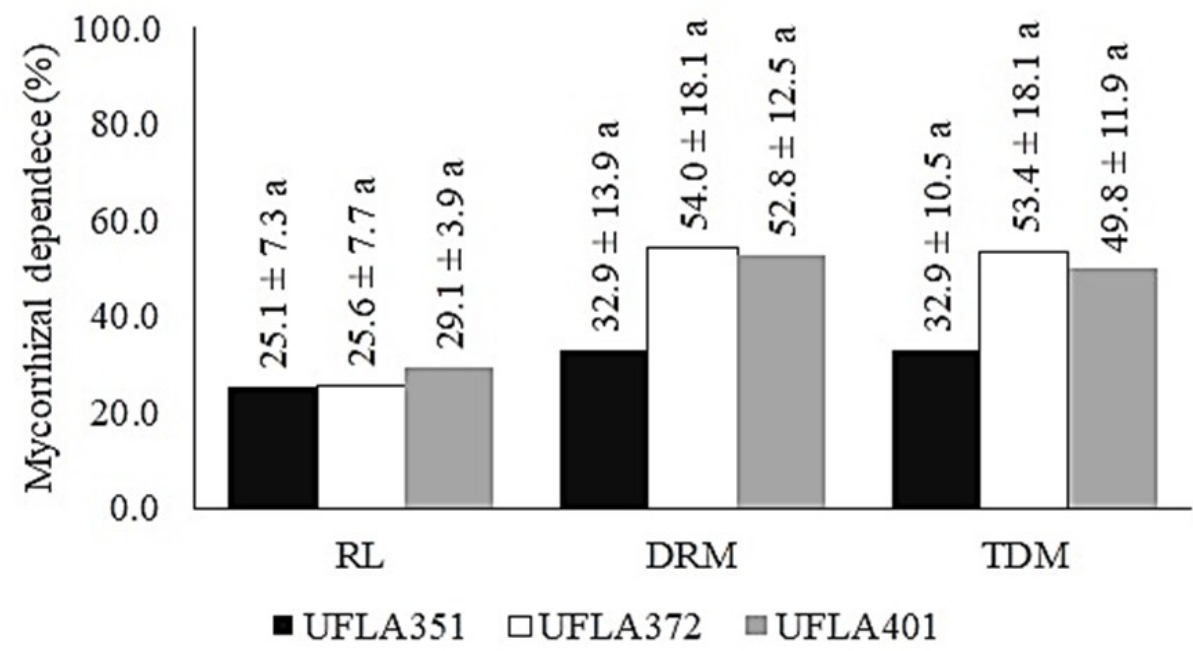

Figure 1. Mycorrhizal dependence of $P$. millegrana plants cultivated with UFLA isolates, in the root length (RL), dry root mass (DRM) and total dry mass (TDM) variables, after 90 days of transplanting ${ }^{1,2}$. ${ }^{1}$ Treatments: control - without AMF; UFLA351 - R. clarum; UFLA372 - C. etunicatum; and UFLA401 - A. morrowiae; ${ }^{2}$ Means followed by the same letter, by variable, do not differ by the Tukey's test at $5 \%$ probability.

Machineski, Balota and Souza (2011) reported that the mycorrhizal dependence increased from 25 to $54 \%$ in P. millegrana. This indicates a moderate to high dependence, which may also have contributed to the increase in phosphorus to maintain the symbiosis and reduce the amount of phosphorus in the plants leaves cultivated with the AMF isolates when compared to the control (Table 2; Figure 1).

Cavagnaro et al. (2014) reported that $P$. dilatatum was responsive to the inoculation of AMF probably due to the high colonization rate $(63 \%$ to $80 \%)$. However, $P$. millegrana cultivated with UFLA351 was responsive to mycorrhizal colonization by $11.9 \%$ only (Table 1 ). This result corroborates that of Santos et al. (2018a), where the efficiency of symbiosis is not always correlated to high mycorrhizal colonization.

Regarding tiller emergence, Cavagnaro et al. (2014) observed that $P$. dilatatum inoculated with Glomus mixture did not increase tiller emergence, as observed in $P$. millegrana cultivated with UFLAs isolates belonging to the genera Gigaspora, Rhizoglomus, Claroideoglomus and Acaulospora. Holanda et al. (2017) reported that tiller emergence of $P$. millegrana was inversely correlated to the amount of water available in the soil. These authors, also concluded that the high biomass grass reduce soil water and stimulates tiller formation, perhaps as a survival strategy. In this study conducted in the greenhouse equipped with irrigation systems, the surviral strategy concept might not be applicable.

$P$. millegrana grass cultivated with exotic AMF isolates have thin roots, as the vetiver grass (SANTOS et al., 2018a), which offers advantages in reducing soil erosion (MACHADO et al., 2015). The colonization of $P$. millegrana grass by exotic AMF may be important in studies, especially those of slope stabilization as performed by Holanda et al. (2017). However, soil erosion control by plants such as $P$. millegrana is remarkable and should be more investigated. Specifically, the association with exotic AMF and native DSE fungi in order to favor soil conservation influence the development and survival of grasses under adverse conditions. These is very important in regions with low fertility soils and water deficit such as in Northeastern Brazil.

\section{CONCLUSIONS}

P. millegrana grass is colonized by exotic AMF belonging to Rhizoglomus clarum, Claroideoglomus etunicatum and Acaulospora morrowiae.

$P$. millegrana is also colonized by native DSE 
fungi, but they do not interfere either with the colonization by UFLA nor in in plant development. $P$. millegrana responds to the inoculation of UFLA isolates of exotic AMF.

The process of the seeds surface disinfection does not eliminate endophytic microorganisms, what presence may influence plant colonization by AMF, as well as in the development of the host plant.

\section{REFERENCES}

ALFENAS, A. C.; MAFIA, R. G. Métodos em fitopatologia. 1. ed. Viçosa, MG: UFV, 2007. 382 p.

AZEVEDO, J. L. Microorganismos endofíticos. In: MELO, I. S.; AZEVEDO, J. L. (Eds.). Ecologia Microbiana. Jaguariúna: Embrapa, 1998. v. 1, cap. 4, p. 117-137.

BALESTRINI, R. et al. Plant-soil biota interactions. Soil Microbiology, Ecology and Biochemistry, London: Elsevier, 2014. v. 1, cap. 11, p. 311-338.

BARROW, J. R.; OSUNA, P. Phosphorus solubilization and uptake by dark septate fungi in fourwing saltbush, Atriplex canescens (Pursh) Nutt. Journal of Arid Environments, v. 51, n. 7, p. 449459, 2002.

CAVAGNARO, R. A. et al. A. Screening of biomass production of cultivated forage grasses in response to mycorrhizal symbiosis under nutritional deficit conditions. Japanese Society of Grassland Science, v. 60, n. 1, p. 178-184, 2014.

CHANNABASAVA, A.; LAKSHMAN, H. C.; MUTHUKUMAR, T. Fly ash mycorrhizoremediation through Paspalum scrobiculatum L., inoculated with Rhizophagus fasciculatus. Comptes Rendus Biologies, v. 338, n. 1, p. 29-39, 2015.

CUI, H. et al. The combined effects of cover crops and symbiotic microbes on phosphatase gene and organic phosphorus hydrolysis in subtropical orchard soils. Soil Biology \& Biochemistry, v. 82, n. 1, p. 119-126, 2015.

DICKSON, S.; SMITH, F. A.; SMITH, S. E. Structural differences in arbuscular mycorrhizal symbioses: more than 100 years after Gallaud, where next?. Mycorrhiza, v. 17, n. 5, p. 375-393, 2007.

DUPONT, P. Y. et al. Fungal endophyte infection of ryegrass reprograms host metabolism and alters development. New Phytologist, v. 208, n. 4, p. 1227 $-1240,2015$.

GARCIA, I. V.; MENDOZA, R. E. Relationships among soil properties, plant nutrition and arbuscular mycorrhizal fungi-plant symbioses in a temperate grassland along hydrologic, saline and sodic gradients. FEMS Microbiology Ecology, v. 63, n. 3, p. 359-371, 2008.

GERDEMANN, J. W.; NICOLSON, T. H. Spores of mycorrhizal endogone species extracted from soil by wet-sieving and decanting. Transactions of British Mycological Society, v. 46, n. 2, p. 235-244, 1963.

GERLACH, N. et al. An integrated functional approach to dissect systemic responses in maize to arbuscular mycorrhizal symbiosis. Plant, Cell \& Environment, v. 38, n. 8, p. 1591-1612, 2015.

GIOVANNETTI, M.; MOSSE, B. An evaluation of techniques for measuring vesicular arbuscular mycorrhizal infection in roots. New Phytologist, v. 84, n. 3, p. 489-500, 1980.

HEIJDEN, M. G. A. V. et al. Mycorrhizal ecology and evolution: the past, the present, and the future. New Phytologist, v. 205, n. 4, p. 1406-1423, 2015.

HOLANDA, F. S. R. et al. Biotechnical potential of Paspalum submitted to simple superphosphate doses and moisture content. Revista Scientia Agraria, v. 18 , n. 4 , p. 43-49, 2017.

HOLANDA, F. S. R.; ROCHA, I. P.; OLIVEIRA, V. $\mathrm{S}$. Estabilização de taludes marginais com técnicas de bioengenharia de solos no Baixo São Francisco. Revista Brasileira de Engenharia Agrícola e Ambiental, v. 12, n. 6, p. 570-575, 2008.

JALONEN, R. et al. Arbuscular mycorrhizal symbioses in a cut-and-carry forage production system of legume tree Gliricidia sepium and fodder grass Dichanthium aristatum. Agroforestry Systems, v. 87, n. 2, p. 319-330, 2013.

LOPES, L. J. O. et al. Produção de propágulos micorrízicos em sorgo e/ou em braquiária. Scientia Plena, v. 14, n. 8, p. 1-8, 2018.

MACHADO, L. et al. Contribuição do sistema radicular do capim-vetiver para estabilização do talude do Rio São Francisco. Semina: Ciências Agrárias, v. 36, n. 4, p. 2453-2464, 2015.

MACHINESKI, O.; BALOTA, E. L.; SOUZA, J. R. P. Resposta da mamoneira a fungos micorrízicos arbusculares e a níveis de fósforo. Semina: Ciências Agrárias, v. 32, n. 4, p. 1855-1862, 2011.

MALAVOLTA, E.; VITTI, G. C.; OLIVEIRA, S. A. Avaliação do estado nutricional das plantas: princípios e aplicações. 2. ed. Piracicaba, SP: Associação Brasileira para Pesquisa do Fosfato, 
1997. $238 \mathrm{p}$.

MANDYAM, K.; JUMPPONEN, A. Seasonal and temporal dynamics of arbuscular mycorrhizal and dark septate endophytic fungi in a tallgrass prairie ecosystem are minimally affected by nitrogen enrichment. Mycorrhiza, v. 18, n. 3, p. 145-155, 2008.

MONROY, H. J. et al. Influencia de las coberturas em cultivos de cítricos sobre los hongos formadores de micorrizas arbusculares em Oxisoles del piedemonte Ilanero colombiano. Corpoica Ciencia Tecnología Agropecuaria, v. 14, n. 1, p. 53-65, 2013.

NEWSHAM, K. K. A. Meta-analysis of plant responses to dark septate root endophytes. New Phytologist, v. 190, n. 3, p. 783-793, 2011.

OKONJI, C. J. et al. Effects of arbuscular mycorrhizal fungal inoculation on soil properties and yield of selected rice varieties. Journal of Agricultural Sciences, v. 63, n. 2, p. 153-170, 2018.

OLIVEIRA, C. O. et al. Paspalum (Poaceae) no Rio Grande do Norte, Brasil. Rodriguésia, v. 64, n. 4, p. 847-862, 2013.

PEREIRA, G. M. D. et al. Ocorrência de fungos endofíticos "dark septate" em raízes de Oryza glumaepatula na Amazônia. Pesquisa Agropecuária Brasileira, v. 46, n. 3, p. 331-334, 2011.

PLENCHETTE, C.; FORTIN, J. A.; FURLAN, V. Growth response of several plant species to mycorrhizae in a soil of moderate P-fertility. I. Mycorrhizal dependence under field conditions. Plant and Soil, v. 70, n. 2, p. 199-209, 1983.

RIBEIRO, K. G. et al. Isolamento, armazenamento e determinação da colonização por fungos "dark septate" a partir de plantas de arroz. Revista Agro@ambiente on-line, v. 5, n. 2, p. 97-105, 2011.

RIVERO, J. et al. Root metabolic plasticity underlies functional diversity in mycorrhiza-enhanced stress tolerance in tomato. New Phytologist, v. 220, n. 4, p. 1322-1336, 2018.

SANTOS, J. S. et al. Arbuscular mycorrhizal fungi and dark septate endophytica fungi on the biomass development of vetiver grass. Revista Caatinga, v. 31, n. 3, p. 602-611, 2018a.

SANTOS, T. A. C. et al. Microbial Interactions in the development of the biomass of gliricidia. Revista Caatinga, v. 31, n. 3, p. 612-621, 2018 b.
SECRETARIA ESTADUAL DE MEIO AMBIENTE E RECURSOS HÍDRICOS SEMARH - .Banco de dados meteorológicos do Estado de Sergipe. Disponível em: <http:// www.semarh.se.gov.br/meteorologia/>. Acesso em: 02 out. 2018.

SILVA, M. O. et al. Bacteria associated with sugarcane in Northeastern Brazil. African Journal of Microbiology Research, v. 10, n. 37, p. 1586$1594,2016$.

TEUTSCHEROVA, N. et al. Native arbuscular mycorrhizal fungi increase the abundance of ammonia-oxidizing bacteria, but suppress nitrous oxide emissions shortly after urea application. Geoderma, v. 338, n. 1, p. 493-501, 2019.

TRESEDER, K. K; ALLEN, M. F. Direct nitrogen and phosphorus limitation of arbuscular mycorrhizal fungi: a model and filed test. New Phytologist, v. 155 , n. 3 , p. $507-515,2002$.

UMA, E. et al. Tree species as hosts for arbuscular mycorrhizal and dark septate endophytes fungi. Journal of Forestry Research, v. 23, n. 4, p. 641649, 2012.

VOLPE, V. et al. The association with two different arbuscular mycorrhizal fungi differently affects water stress tolerance in tomato. Frontiers in Plant Science, v. 9, art. 1480, p. 1-16, 2018.

ZIANE, H. et al. Effects of arbuscular mycorrhizal fungi and fertilization levels on industrial tomato growth and production. International Journal of Agriculture \& Biology, v. 19, n. 2, p. 341-347, 2017.

WHITE, B. L. A.; SILVA, M. F. A. Avaliação das condições microclimáticas no interior de fragmentos de Mata Atlântica em distintos graus de conservação no município de São Cristóvão, Sergipe. In: SEABRA, G. (Eds.). Educação Ambiental \& Biogeografia. Uberlândia: Editora Barlavento, 2016. v. 1 , cap. 55 , p. 571-578.

YAN, J. F. et al. Do endophytic fungi grow throught their hosts systemically? Fungal Ecology, v. 13, n. 1, p. 53-59, 2015. 